\title{
Purification, Characterization, and Inhibition of Tyrosinase from Jerusalem Artichoke (Helianthus Tuberosus L.) Tuber
}

\author{
Omar Younis AL-Abbasy*1, Wathba Idrees Ali ${ }^{1}$, \\ Aya Ihsan Rashan ${ }^{2}$, Shihab Ahmed AL-Bajari ${ }^{3}$
}

\begin{abstract}
Background: Because it tends to cause deterioration in the quality of food and appearance, food browning is unacceptable. Tyrosinase, which catalyzes the transformation of mono phenolic compounds into oquinones, has been associated with this phenomenon. Natural anti-browning agents were used to help avoid the enzymatic browning that occurs in many foods.

Methods: Tyrosinase of Jerusalem Artichoke tubers was purified through (NH4)2SO4 sedimentation, dialysis, chromatography, and finally gel electrophoresis. The purified enzyme was characterized and inhibited by rosemary extracts.

Results: Purification of tyrosinase from Jerusalem Artichoke tuber were accomplished. The specific activity at the final step of purification increased to $14115.76 \mathrm{U} / \mathrm{mg}$ protein with purification fold 32.89 using CM-Cellulose chromatography. The molecular mass was evaluated by electrophoresis and found to be $62 \mathrm{KDa}$. Maximum tyrosinase activity was found at $30{ }^{\circ} \mathrm{C}, \mathrm{pH} 7.2$, and higher affinity towards Ltyrosine. Inhibition percentage of heated extracts for leaves and flowers on tyrosinase activity was better than nonheated with $29.65 \%$ and $23.75 \%$, respectively. The kinetic analysis exposed uncompetitive inhibition by leaves and flowers heated extracts.

Conclusions: In this study, we concluded the usage of natural anti-browning inhibitors like rosemary extract be able to be castoff to substitute the chemical agents which might be dangerous to social healthiness. Natural anti-browning agents can be used to prevent the browning of many foods.
\end{abstract}

Keywords: Jerusalem artichoke, Rosemary, Tyrosinase.

\section{Introduction}

Jerusalem artichoke (Helianthus tuberosus L.) tuber is a perpetual herb, straight and rhizomatous. It is grown-up mostly as a onceyearly even though it is perennial (1). It is originated from North America, and extensively cultivated between $40^{\circ} \mathrm{C}$ and $55^{\circ} \mathrm{C}$ (2). The tubers have abundant content of carbohydrate especially inulin, nonetheless relatively little contents of protein and fiber (3). The protein content of tubers ranges from 5 to $12 \%$, and sulfur amino acids make up the bulk of this content (4). The mineral content in the flowering of the Jerusalem artichoke stage appears to be sufficient for $\mathrm{K}, \mathrm{Ca}, \mathrm{Mg}$, but insufficient for $\mathrm{P}$ (5). In comparison to traditional crops, Jerusalem artichoke has several advantageous features, such as high growth rate, strong frost, drought and soil type tolerance, strong resistance to pathogens, and plant diseases (6). Tyrosinase (EC 1.14.18.1) is classified as an oxidoreductase enzyme which distributed widely in the kingdom of 
plant that has been discovered in many other vegetables and fruits. It catalyzes monophenol hydroxylation to form diphenol that then oxidized into quinone compound, which then polymerizes and forms black melanin pigment (7).

It's a plastid-localized enzyme that is usually separated by cell compartments from its substrate, phenolic compounds. The browning reaction happens when interaction between enzyme and phenolic compounds is caused by mechanical injury and tissue damage, such as slicing, peeling, and cutting on plant cells (8). To maintain food quality and ingratiate consumer needs, control of enzymatic browning was essential. Because of the attentiveness of the side special effects that may result from chemicals, the food productiveness is at present demanding to exclude the use of chemicals in foodstuff. In several plants, such as potato (9), and quince (10), tyrosinase inhibitors taking place in natural means have been considered. The inhibition of ginger tyrosinase by honey as a natural enzymatic antibrowning was reported (11). The enzymatic browning inhibition was achieved in potato puree by rice bran extract, and the reason perhaps due to the extract involves cysteine that has shown chelating activity (12). An onion extract was used to suppress the activity in the juices of apples (13). Limited evidence is available for exactly how natural inhibitors may impact the activity of Jerusalem artichoke tyrosinase.

Rosemary (Rosmarinus officinalis L.), a perennial aromatic woody shrub, its leaves resemble pine. The leaves are used as a flavor in foods. It grows in warm regions, so the Mediterranean region and Asia were their original habitat. It contains many phytochemicals as camphor, rosmarinic acid, caffeic acid, and ursolic. Many antioxidants were determined in this plant such as carnosic acid and carnosol (14-15), as well as polyphenolic compounds like quercetin, apigenin, luteolin, and catechin (16). The research aims to separate and estimate the molecular weight of tyrosinase from Jerusalem artichoke tuber, then inhibit it using some rosemary extracts and reduce the enzymatic browning that is negative for many foods.

\section{Materials and Methods Chemical and Plant material}

Jerusalem artichoke originated from Nineveh province; Iraq was used in this work. It was bought from a Mosul local market. Rosemary was harvested from the herbarium of the forest department of agriculture and forest College, Mosul University. All chemicals used were of analytical grade which was obtained from Sigma and Molecule Chemical Company.

\section{Tyrosinase activity}

According to the Worthington Manual Decker (1977) method (17), the activity of tyrosinase was determined spectrophotometrically using $2 \mathrm{mM}$ tyrosine as a substrate. The method is based on the oxidation of tyrosine to L-DOPA. The enzymatic activity was measured by following an increase in absorption at $280 \mathrm{~nm}$ for 5 minutes per 15 seconds. Each measurement was made in duplicate. One unit of tyrosinase activity is described as an enzyme quantity that caused an increase in absorption of $0.001 / \mathrm{min}$.

\section{Protein Determination}

The protein conc. was estimated at $650 \mathrm{~nm}$ by using the standard curve of bovine serum albumin solution ranging from $0-240 \mu \mathrm{g} / \mathrm{ml}$ (18).

\section{Preparation of crude tyrosinase extraction}

Extraction was improved by taking $250 \mathrm{~g}$ from Jerusalem artichoke. After washing and chopping, the homogenization was carried out using $5 \mathrm{~g}$ of Polyethylene glycol, $0.25 \mathrm{~g}$ of ascorbic acid (AA), and $0.1 \mathrm{~mL}$ of detergent, Triton X-100 in $300 \mathrm{~mL} 100 \mathrm{mM}$ phosphate buffer (pH 6.8) at $4{ }^{\circ} \mathrm{C}$ for 2 min using a blender. After filtration, the homogenate was centrifuged at $2016 \mathrm{~g}$ at $4{ }^{\circ} \mathrm{C}$ for $20 \mathrm{~min}$. The supernatant extract acquired was considered crude tyrosinase. 


\section{Purification of tyrosinase by Ammonium sulfate precipitation}

To give a saturation of $80 \%$, ammonium sulfate salt was slowly added to the crude tyrosinase extract at $4{ }^{\circ} \mathrm{C}$. Precipitation was permitted overnight, followed by centrifugation for $20 \mathrm{~min}$ at $2016 \mathrm{~g}$. In a minimum of $100 \mathrm{mM}$ phosphate buffer $(\mathrm{pH}$ 6.8 ), the precipitate was dissolved and dialyzed via a $10 \mathrm{kDa}$ cut-off membrane for 24 hours, with four changes in the same buffer at $4{ }^{\circ} \mathrm{C}$ and then centrifuged at $2744 \mathrm{~g}$ for 5 minutes and the clear supernatant was used in the following procedure (19).

\section{DEAE-Cellulose chromatography}

Dialyzed enzyme was applied to DEAECellulose column $(2.5 \times 40 \mathrm{~cm})$ before equilibrated with the $100 \mathrm{mM}$ phosphate buffer ( $\mathrm{pH}$ 6.8). After washing with double bed volumes of the original buffer, elution was completed at a flow rate of $1 \mathrm{ml} / \mathrm{min}$. Fractions showing tyrosinase activity were collected after monitoring at intervals of the individual fraction $(5 \mathrm{ml})$, then dialyzed and lyophilized.

\section{CM-cellulose chromatography}

The lyophilized peak attained from the previous step was dissolved in $5 \mathrm{ml}$. of the same buffer. The enzyme solution was placed onto CM-cellulose column $(2 \times 25 \mathrm{~cm})$ before equilibrated with buffer. The purification was accomplished at a flow rate of $1 \mathrm{ml} / \mathrm{min}$. Fractions showing tyrosinase activity were collected after monitoring at intervals of an individual fraction $(3 \mathrm{ml})$ and then lyophilized (19).

\section{Determination of Molecular weight}

The molecular mass of purified tyrosinase was estimated by using Laemmli (1970) method (20). The protein solution was heated for 5 minutes at $100{ }^{\circ} \mathrm{C}$. The stacking gel was run at a voltage supply of $70 \mathrm{~V}$ for about 45 minutes, and the separating gel was run at a voltage supply of $100 \mathrm{~V}$ for about 90 minutes. The Coomassie Blue staining technique was used to visualize the protein bands, and the molecular weight was calculated using proteins of known molecular weight ranged between 14-116 KDa.

Determination of optimum pH, temperature, and Substrate specificity

The optimum $\mathrm{pH}$ for the purified tyrosinase was investigated by incubating the enzyme at a various $\mathrm{pH}$ range of $100 \mathrm{mM}$ phosphate buffer solutions between 5.6-8. The optimum temperature was investigated by incubating the enzyme at temperatures from 10 to $70{ }^{\circ} \mathrm{C}$. Enzyme specificity toward several substrates was studied by using $2 \mathrm{mM}$ of phenol, tyrosine, resorcinol, catechol, pyrocatechol, L-Dopa, guiacol, and gallic acid.

\section{Inhibitors effects}

The effects of (L-glycin, L- cysteine, ascorbic acid, cinnamic acid, citric acid, EDTA, and SDS) as inhibitors on Jerusalem artichoke purified tyrosinase activity were examined with presence two conc. ( 1 and $5 \mathrm{mM}$ ), after incubating $0.1 \mathrm{ml}$ of each inhibitor with $0.2 \mathrm{ml}$ of an enzyme for $30 \mathrm{~min}$. Inhibition percentage was evaluated by the equation: Inhibition percentage $=(($ Acont. - Ainh.$) /$ Acontrol $) \times$ 100.

\section{Carbohydrates Effect}

The effects of some carbohydrates (sucrose, galactose, fructose, glucose ribose) on Jerusalem artichoke purified tyrosinase activity were examined at two constant carbohydrate conc. (1 and $2 \mathrm{mM}$ ), after incubating $0.1 \mathrm{ml}$ of each carbohydrate with $0.2 \mathrm{ml}$ of an enzyme for $30 \mathrm{~min}$.

\section{Effect of natural inhibitors}

Rosemary leaves and flower extracts were freshly used as natural inhibitors with a concentration of $10 \mathrm{mg} / \mathrm{mL}$ as a stock solution (21). Extraction was done by homogenizing individually one hundred grams with $100 \mathrm{~mL}$ of distilled water for 1 minute at a maximum speed at $22400 \mathrm{~g}$. They filtered the homogenates via cloth. At $2016 \mathrm{~g}$ for $25 \mathrm{~min}$ at $4{ }^{\circ} \mathrm{C}$, the filtrate has been centrifuged. By Buchner funnel, the supernatant obtained 
was filtered to use as a new inhibitor. To make heated inhibitors, the inhibitor extracts were incubated at $90{ }^{\circ} \mathrm{C}$ for 20 minutes. The inhibitors were centrifuged for 1 minute at 8064 g. To $9.9 \mathrm{~mL}$ distilled water, $100 \mu \mathrm{L}$ of heated inhibitors were added for preparing 10 $\mathrm{mg} / \mathrm{mL}$ before use.

\section{Tyrosinase inhibition assay}

Inhibition of tyrosinase activity was assayed after incubating $0.1 \mathrm{ml}$ of each inhibitor with $0.2 \mathrm{ml}$ of an enzyme for $30 \mathrm{~min}$. The conc. ranges of extracts used to calculate IC50 values was $1-10 \mathrm{mg} / \mathrm{mL}$. Tyrosine concentration was prepared between (0.25- 10 $\mathrm{mM}$ ) to investigate inhibition mode.

\section{Results}

\section{Isolation and Purification}

After precipitating with $80 \%$ (NH4)2SO4, the enzyme-specific activity has resulted from $293.49 \mathrm{U} / \mathrm{mg}$ protein with purification fold 0.68 compared to crude sample. The results shows that tyrosinase from Jerusalem artichoke was successfully purified to 32.89 purification fold with 22.86 total recovery. As can be noticed, from a primary value of $429.102 \mathrm{U} / \mathrm{mg}$ protein, specific activity increased to $14115.76 \mathrm{U} / \mathrm{mg}$ protein, however, the protein conc. decreased afterward successive purification steps (Table 1). The elution profile of tyrosinase from both DEAECellulose and CM-Cellulose chromatography revealed a single peak (Figs. 1 and 2).

Table 1. tyrosinase purification steps from Jerusalem artichoke (Helianthus tuberosus L.).

\begin{tabular}{lllllll}
\hline Purification steps & $\begin{array}{l}\text { Volume } \\
(\mathbf{m l})\end{array}$ & $\begin{array}{l}\text { Total } \\
\text { protein } \\
(\mathbf{m g})\end{array}$ & $\begin{array}{l}\text { Total } \\
\text { activity } \\
\text { U* }\end{array}$ & $\begin{array}{l}\text { Specific activity } \\
\text { (U/mg protein) }\end{array}$ & Yield \% & $\begin{array}{l}\text { Purification } \\
\text { Fold }\end{array}$ \\
\hline Crude extract & 118 & 34.676 & 14879.55 & 429.102 & 100 & 1 \\
Ammonium sulfate & 21 & 22.620 & 6638.87 & 293.49 & 44.617 & 0.68 \\
Dialysis & 15 & 8.013 & 4214.22 & 525.92 & 28.322 & 1.22 \\
DEAE-Cellulose & 67 & 0.833 & 3970.23 & 4766.18 & 26.68 & 11.10 \\
CM-Cellulose & 43 & 0.241 & 3401.9 & 14115.76 & 22.86 & 32.89 \\
\hline
\end{tabular}

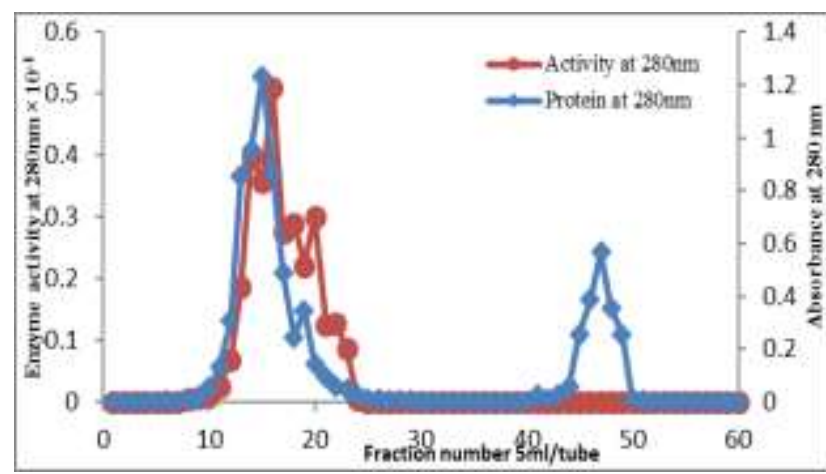

Fig. 1. Elution profile of tyrosinase from Jerusalem Artichoke on DEAE-cellulose column.

\section{Molecular weight}

The molecular weight of the main band of partially purified tyrosinase from Jerusalem

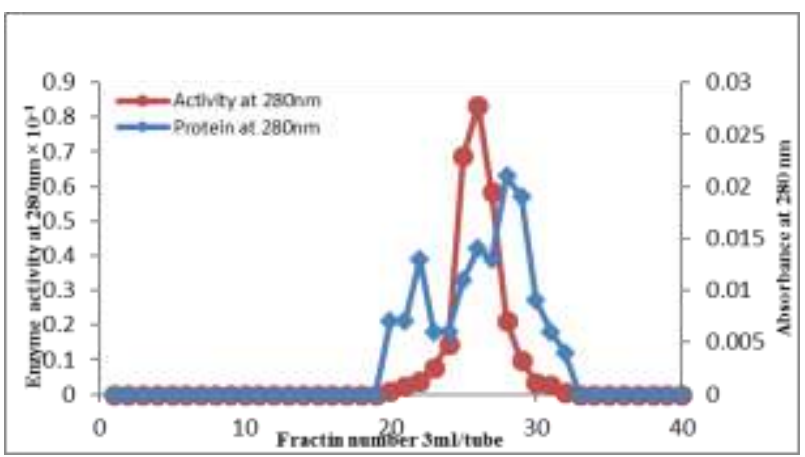

Fig. 2. Elution profile of tyrosinase from Jerusalem Artichoke on CM-cellulose column.

artichoke was approximately calculated to be $62 \mathrm{kDa}$ (Fig. 3). 


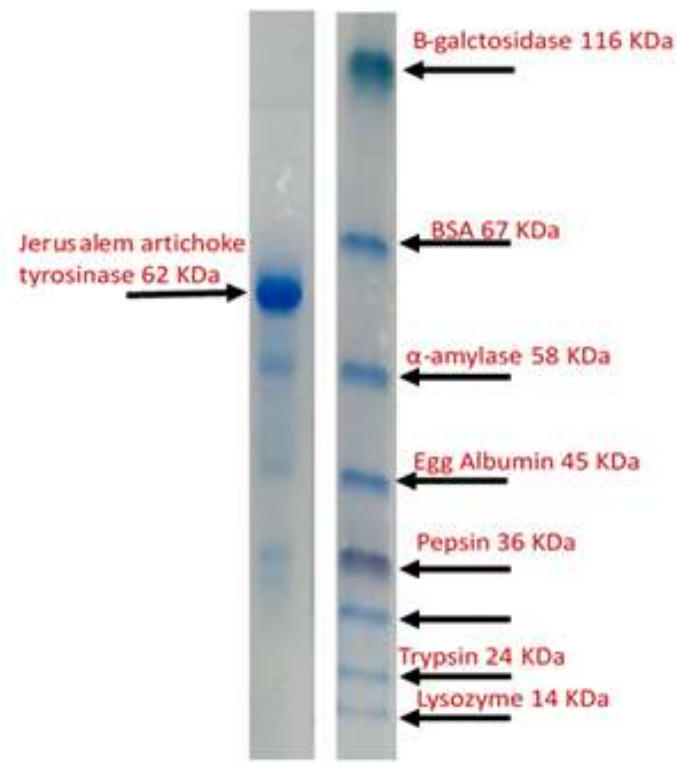

Fig. 3. SDS-PAGE of tyrosinase obtained from Jerusalem artichoke. Lane 1: standards molecular weight, lane 2: Jerusalem artichoke tyrosinase.

\section{Optimal pH}

Enzymes are highly sensitive to $\mathrm{pH}$ variation, which would affect tyrosinase's external conformation. The optimal $\mathrm{pH}$ for the activity charge, solubility, binding capability, and of the Jerusalem Artichoke tyrosinase was found to be 7.2 (Fig. 4).

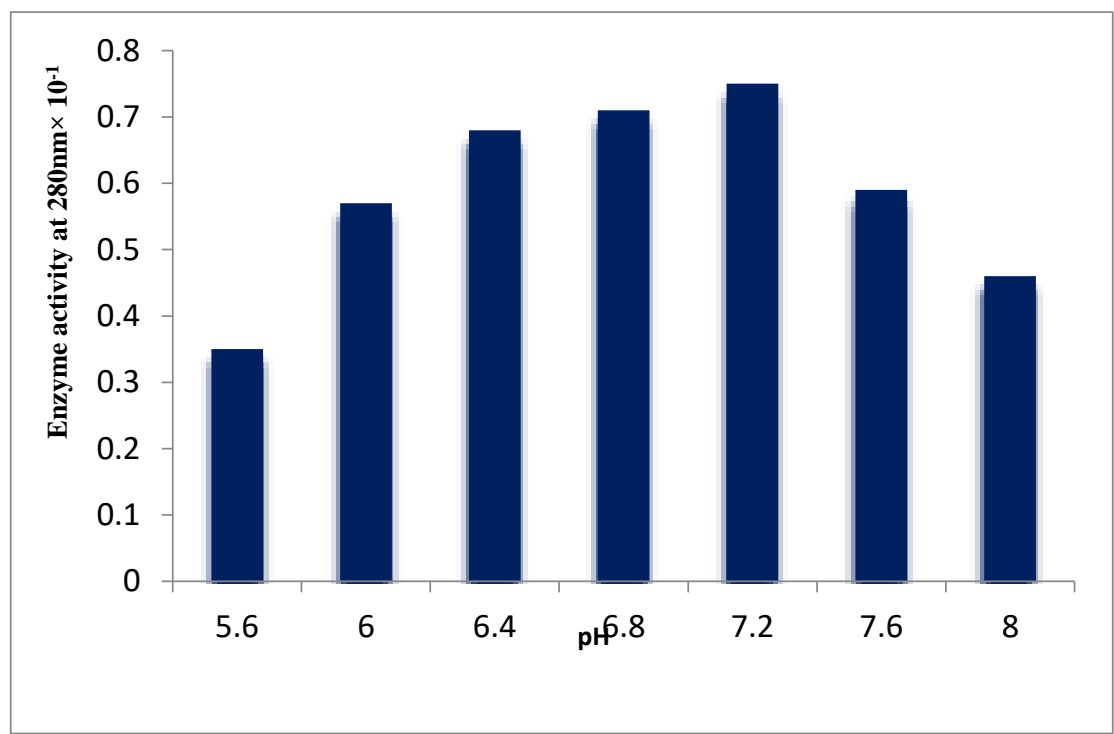

Fig. 4. $\mathrm{pH}$ optima of Jerusalem Artichoke tyrosinase.

\section{Optimal Temperature}

The influence of temperature is varies based on numerous variables, very high temperatures can change an enzymesubstrate complex's rupture speed. Figure 4 demonstrates that the Jerusalem Artichoke's tyrosinase is extremely active at $30{ }^{\circ} \mathrm{C}$. After this temperature, the activity declined gradually. 


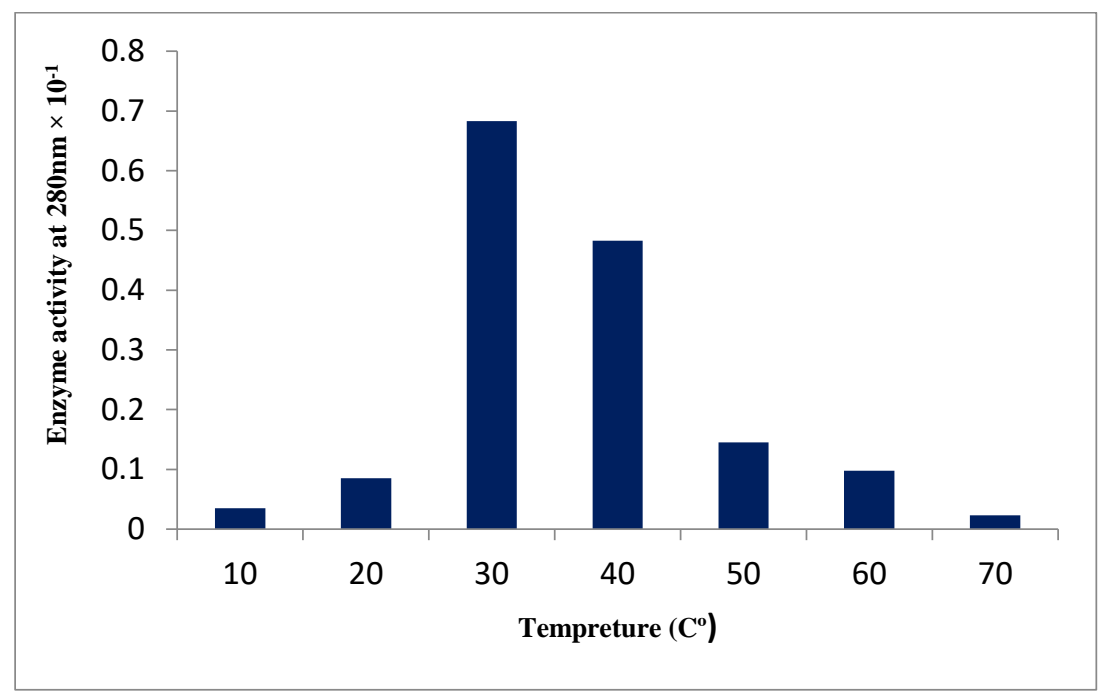

Fig. 5. Temperature optima of Jerusalem Artichoke tyrosinase.

\section{Substrate specificity}

The substrate specificity of an enzyme differs widely depending on the sorts of substrate and enzyme purity. Tyrosinase oxidized all substrates significantly including the study except gallic acid (Table 2). The substrate with the maximum activity was established to be Ltyrosine, but guiacol revealed the lowest activity.

Table 2. Substrate's specificity of purified tyrosinase.

\begin{tabular}{lll}
\hline Substrate & Conc.(mM) & Relative activity $\mathbf{( \% )}$ \\
\hline Phenol & 2 & 74.8 \\
Tyrosine & 2 & 100 \\
resorcinol & 2 & 74.8 \\
Catechol & 2 & 91.5 \\
Pyrocatechol & 2 & 89.4 \\
L- Dopa & 2 & 46.0 \\
Guiacol & 2 & 22.4 \\
Gallic acid & 2 & 0 \\
\hline
\end{tabular}

\section{Inhibitor study}

In a recent study, the influence of the inhibitor on Jerusalem Artichoke tyrosinase is presented in Table 3. The most effective

inhibitors were citric acid and ascorbic acid respectively, however, the weak inhibitor was SDS.

Table 3. Effect of different inhibitors on purified tyrosinase activity.

\begin{tabular}{lll}
\hline Inhibitors & Conc. $\mathbf{m M}$ ) & \% Inhibition \\
\hline L- cysteine & 1 & 26.9 \\
& 5 & 56.10 \\
\hline L- glycin & 1 & 12.30 \\
& 5 & 36.30 \\
\hline Ascorbic acid & 1 & 57.75 \\
& 5 & 77.11 \\
\hline Citric acid & 1 & 65 \\
& 5 & 87.50 \\
\hline Cinnamic acid & 1 & 34.60 \\
\hline EDTA & 5 & 58.45 \\
\hline DS & 1 & 24 \\
& 5 & 46.20 \\
\hline
\end{tabular}


Carbohydrates Effects

The effects of many carbohydrates on the activity of purified tyrosinase have been investigated and the enzyme is activated by all carbohydrates except galactose.

Table 4. Carbohydrates effect on purified tyrosinase activity.

\begin{tabular}{lll}
\hline \multicolumn{1}{c}{ Carbohydrates } & Conc. $(\mathbf{m M})$ & \% Activation \\
\hline Sucrose & 1 & 7.5 \\
& 2 & 9.1 \\
Galactose & 1 & --- \\
& 2 & -- \\
Fructose & 1 & 12.5 \\
& 2 & 16.1 \\
Glucose & 1 & 8.5 \\
& 2 & 11.2 \\
Ribose & 1 & 4 \\
\end{tabular}

\section{Effect of rosemary extracts}

Table 5 illustrates the inhibitory effect of rosemary leaves and flower extracts on purified Jerusalem Artichoke tyrosinase

activity. The heated extracts demonstrated a stronger inhibition percentage than nonheated.

Table 5. Effect of rosemary extracts on tyrosinase activity.

\begin{tabular}{lll}
\hline Plant Part & Extract $(\mathbf{2} \mathbf{~ m g} / \mathbf{m l})$ & \%Inhibition \\
\hline Leaves & Nonheated & 17.55 \\
& Heated & 29.65 \\
Flowers & Nonheated & 15.45 \\
& Heated & 23.75 \\
\hline
\end{tabular}

When using the heated extract of rosemary leaves and flowers as natural inhibitors at a concentration (IC50) of 4.2 and $5.7 \mathrm{mg} / \mathrm{ml}$ respectively, the results indicated that the inhibition of the purified enzyme was uncompetitive as explaining in Figures 5 and 6 respectively. Through Lineweaver - Burk plot, the values of $\mathrm{Km}$ and Vmax decreased compared to the enzyme without inhibitors (Table 6).

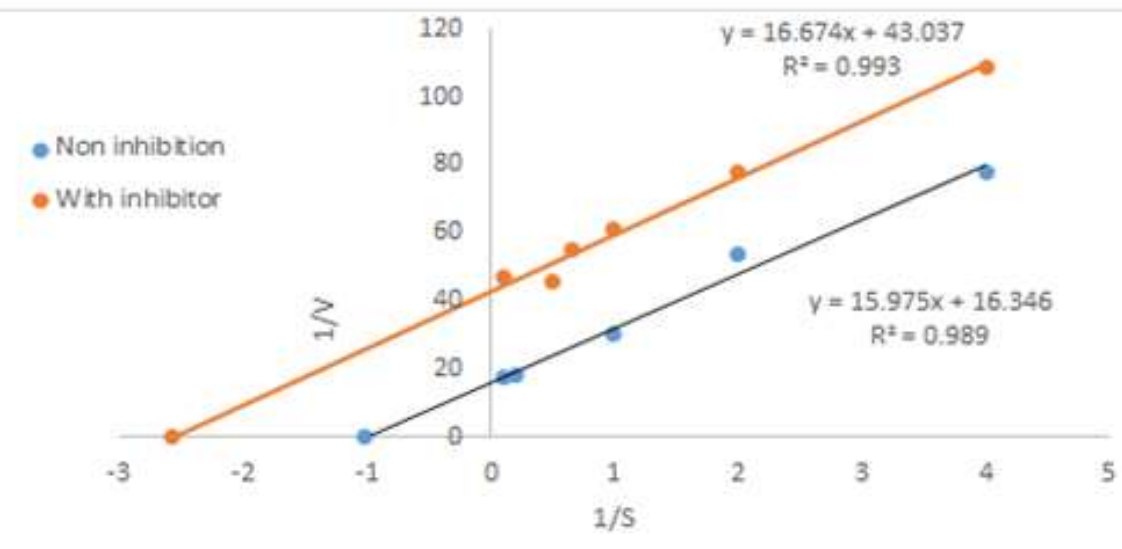

Fig. 6. Inhibition type of tyrosinase by heated extract of rosemary leaves. 


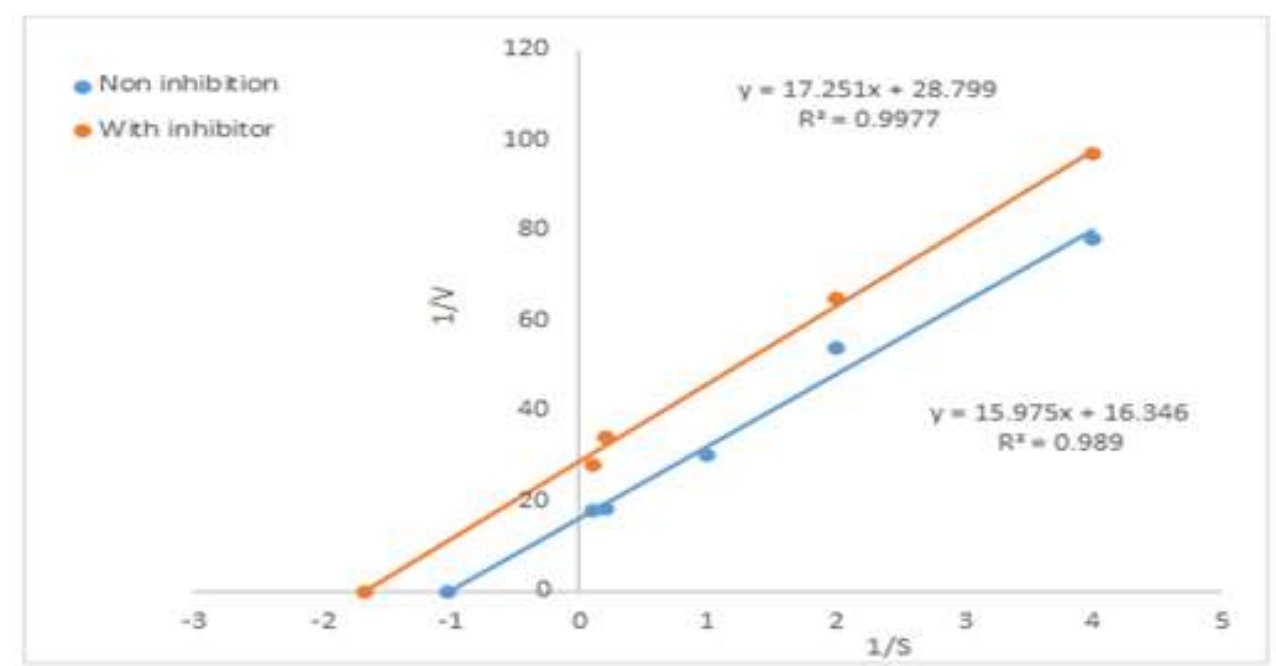

Fig. 7. Inhibition type of tyrosinase by heated extract of rosemary flowers.

Table 6. The kinetic parameters of purified Jerusalem Artichoke tyrosinase.

\begin{tabular}{lllll}
\hline Inhibitors & IC50 $(\mathbf{m g} / \mathbf{m l})$ & Inhibition type & Km $(\mathbf{m M})$ & Vmax U/ml.min \\
\hline Control & --- & -- & 0.98 & 349.55 \\
\hline Leaves heated extract & 4.2 & Uncompetitive & 0.38 & 131.8 \\
flowers heated extract & 5.7 & Uncompetitive & 0.6 & 194.83 \\
\hline
\end{tabular}

\section{Discussion}

The extraction of tyrosinase was accomplished in presence of polyethylene glycol and AA, which have been used to combine phenolic compounds to prevent inhibiting enzymes and reduce quinones. Cortez et al (2013) (23) observed after ammonium sulfate saturation of $80 \%$, for sapodilla plum tyrosinase, the specific activity was $762.7 \mathrm{U} / \mathrm{mg}$ protein.

By ammonium sulfate precipitation and DEAE- Cellulose column, tyrosinase from jackfruit waste was purified, the folds of purity increase from 1.19 to 22.9 respectively (24). Tyrosinase in skin and flesh Turkish Jerusalem artichoke were extracted. The purification degrees were 18.0 and 12.1-fold after gel filtration, respectively (25). Artichoke (Cynara scolymus L.) head tyrosinase has been purified by several steps. A 43-fold purifying was obtained at the end of the purification (26). From the information, it could be noted that the process of extraction, the type of raw materials, and the technique of purification are associated with the purification fold and the yield. The determined molecular mass in this study was alike to that molecular mass of $63 \mathrm{kDa}$ of jackfruit waste and $65 \mathrm{kDa}$ of jackfruit bulb (24, 27). However higher than that of purified enzyme from, beetroot $54 \mathrm{kDa}$ (28) and artichoke be $57 \mathrm{kDa}$ (26). These findings confirmed that tyrosinase was a single polypeptide chain (monomer) for Jerusalem artichoke.

Generally, the best $\mathrm{pH}$ of tyrosinase from different plants is typically $4.0-8.0$, according to earlier reports (29). It was informed that the greater $\mathrm{pH}$ of skin Turkish Jerusalem Artichoke was 7.5 (25). The optimum $\mathrm{pH}$ of Artichoke tyrosinase was found to be 7.0 (26). Moreover, the optimal $\mathrm{pH}$ of water yam and tea leaves enzyme was found to be 6.0 and 8.0 respectively (30-31). Alike results were also reported where enzyme revealed a maximum activity at $30^{\circ} \mathrm{C}$ for flesh of Turkish Jerusalem Artichoke (25), and eggplants (32). On the other hand, optimum temperatures of tyrosinase either lower or higher than $30^{\circ} \mathrm{C}$ were observed 
from various sources such as artichoke heads $\left(25^{\circ} \mathrm{C}\right)(33)$, pear $\left(35^{\circ} \mathrm{C}\right)(34)$, and quince $(40$ $\left.{ }^{\circ} \mathrm{C}\right)$ (35). This result proposed that a temperature over $60{ }^{\circ} \mathrm{C}$ was useful for enzymatic browning inhibition of Jerusalem Artichoke during storage and processing.

The results of substrate specificity according to the nettle tyrosinase which has the best activity toward L-tyrosine (36). Also, it was an agreement to tea leaves enzyme which had not an activity with gallic acid (37). In contrast, artichoke tyrosinase did not use the monophenols compounds, but did use di- and triphenol compounds (33). The skin and flesh of Turkish Jerusalem Artichoke tyrosinase exhibited activity toward the diphenols, but low activity toward gallic acid (25). The best inhibitors for Rape Flower and jackfruit tyrosinase were determined as citric acid and ascorbic acid (27). The influences of amino acid, cysteine, and glycine on the activity of tomatoes enzyme were evaluated and the results were mentioned that cysteine had been the least potent inhibitor (38). Ginseng tyrosinase activity inhibited by AA and kojic acid. In general, certain carboxylic acids play a key role either in reducing quinones or in the active site by chelating the copper ion. In food products, AA used to prevent the browning reaction, is widely used as a reducing agent (39). The best activation was using fructose and glucose, with a proportion of $16.1 \%$ and $11.2 \%$ respectively (Table 4). The corn tassel tyrosinase was activated after using glucose and fructose with $17 \%$ and $16 \%$, respectively (40). The tyrosinase activity of Jack fruit Bulbs was activated by Triton X-100 (27). The results were observed by

\section{References}

1. Dubis B, Jankowski K, Sokólski M, Załuski D, Bórawski P, Szemplinski W. Biomass yield and energy balance of fodder galega in different production technologies: An 11-year field experiment in a large-area farm in Poland. Renewable Energy. 2020;154:813-825.

2. Bogucka PB, Jankowski K. Jerusalem Artichoke: Quality Response to Potassium Fertilization and Irrigation in Poland. Agronomy. 2020; 10:1518; 1-17. using a natural inhibitor, rosemary extracts in agreement with heated and nonheated pineapple extracts which showed the inhibition percentage (17.76-27.03\%) on the ginger enzyme (11).

Similar results have been found that the tyrosinase activity of peach juice inhibited markedly by heated onion extracts (41). Mushroom tyrosinase activity was inhibited by adding $2.5 \mathrm{mg} / \mathrm{ml}$ of ethanolic and hexane extracts of green and roasted coffee (42). The natural antibrowning activity was showed when cinnamon bark oil had 49.51 inhibitory activity on enzyme activity in Musa acuminata, while the aqueous extract of ginger had a $60.90 \%$ inhibitory activity on enzyme activity in Annona muricata (43).

These can be due to that heated extract increased flavonoids and phenolics contents along with increased antioxidant ability, which would also increase inhibition percentage. This can be deduced that the ability to bind enzymes to substrates larger than the fresh extracts might have been reduced by heated extracts. Ginger tyrosinase inhibited uncompetitively by chili pepper extract for individually non-heated and heated extracts (11). Conversely, onion revealed competitive inhibition for yam tyrosinase (22). Rosemary herb may possess some organic acids which bind copper at the active site of an enzyme and help to control browning reaction.

\section{Acknowledgements}

The researchers are truly thankful to University of Mosul which has provided enormous facilities and support to accomplish this work.

3. Hindrichsen IK, Wettstein HR, Machmüller A, Soliva CR, Madsen J, Kreuzer M. Effects of feed carbohydrates with contrasting properties on rumen fermentation and methane release in vitro. Canadian Science Publishing. 2004;84(2):265276.

4. Cieslik E, Gebusia A, Florkiewicz A, Mickowska B. The content of protein and of amino acids in Jerusalem artichoke tubers (Helianthus tuberosus L.) of red variety Rote 
Zonenkugel. Acta Sci Pol Technol Aliment. 2011;10 (4):433-41.

5. Jankowski KJ, Sokólski MM, Dubis B, Szemplinski W. Sweet sorghum-Biomass production and energy balance at different levels of agricultural inputs. A six-year field experiment in north-eastern Poland. European Journal of Agronomy. 2020;119:126119.

6. Gao K, Zhang Z, Zhu T, Coulter JA. The influence of flower removal on tuber yield and biomass characteristics of Helianthus tuberosus L. Industrial Crops and Products. 2020;150:112374. 7. Seonghun K. Antioxidant Compounds for the Inhibition of Enzymatic Browning by Polyphenol Oxidases in the Fruiting Body Extract of the Edible Mushroom Hericium erinaceus. Foods. 2020;9(7):951.

8. Aamir I, Ayesha M, Krystian M, Amjed I, Muhammad FJ, Jinfeng B, et al. Inactivation and structural changes of polyphenol oxidase in quince (Cydonia oblonga Miller) juice subjected to ultrasonic treatment. Journal of the Science of Food and Agriculture. 2020;100(5):2065-2073.

9. Santos M, Lima P, Finger F. Activity of polyphenol oxidase and peroxidase in nondormant potato tubers treated with sprout suppressors. Food Sci Technol. 2020;40(Suppl 1):222-227.

10. Rashan A. I, Al-abbasy O.Y. The Effect of Some Antioxidants Compounds on Enzymatic and Nonenzymic Browning of Quince Juice During Thermal Treatment. Journal of Education Science. 2020;29(4):206-221.

11. Lim WY, Wong Ch. Inhibitory effect of chemical and natural anti-browning agents on polyphenol oxidase from ginger (Zingiber officinale Roscoe). J Food Sci Technol. 2018;55(8):3001-3007.

12. Ali HM, El-Gizawy AM, Saleh MA. The role of various amino acids in enzymatic browning process in potato tubers, and identifying the browning products. Food Chem. 2016;192:879-885.

13. Lee B, Seo JD, Rhee JK, Kim CY. Heated apple juice supplemented with onion has greatly improved nutritional quality and browning index. Food Chem. 2016;201:315-9.

14. Nascimento L, Moraes A, Barbosa CA, Neves C, Sérgio Taube P, Leal Costa C, et al. Bioactive
Natural Compounds and Antioxidant Activity of Essential Oils from Spice Plants: New Findings and Potential Applications. Biomolecules. 2020;7(10):988.

15. Lucas M, Érica M, Lucas M, Louise L, Priscila GM. Rosemary (Rosmarinus officinalis L., syn Salvia rosmarinus Spenn.) and Its Topical Applications: A Review. Plants. 2020;9(5):651.

16. Al-Abbasy OY, Ali WI, Younis SA. Study on inhibitory effect of Rosmarinus officinalis L. Extracts and quercitin on partially purified cow's brain polyamine oxidase. Biochem. Cell. Arch., 2020; 20(2), 5617-5625.

17. Decker AL. Worthington Enzyme Manual, Polyphenol oxidase. Worthington Biochemical Corporation. 1977.

18. Scharcterle GR, Pollack RL. A simplified method for the quantitative assay of small amounts of protein in biologic material. Anal Biochem. 1973;51(2):645-655.

19. Razzaque ZA, Saud MA, Absar N, Hashinaga F. Purification and Characterization of Polyphenoloxidase from Guava Infected with Fruit-rot Disease. Pakistan Journal of Biological Sciences. 2000;3(3):407-410.

20. Laemmli UK. Cleavage of structural proteins during the assembly of the head of bacteriophage T4. Nature. 1970;227:680-685.

21. Gacche RN, Shete AM, Dhole NA, Ghole VS. Reversible inhibition of polyphenol oxidase from apple using L-cysteine. Indian Journal of Chemical Technology. 2006;13(5):459-463.

22. Hosseini MS, Hosseini F, Ahmadi A, Mozafari M, Amjadi I. Antiproliferative Activity of Hypericum perforatum, Achillea millefolium, and Aloe vera in Interaction with the Prostatic Activity of CD82. Rep Biochem Mol Biol.2019; 8(3):260-268.

23. Cortez JT, Méndez CH, Duch ES, Pereira S. Purification and Partial Characterization of Polyphenol Oxidase from Sapodilla Plum (Achras sapota). Food and Nutrition Sciences. 2013;4(7):727-734.

24. Rani G, Arulvel R, Elvarajan S. Studies on kinetic parameters and biochemical characteristics of polyphenol oxidase purified from jackfruit (Artocarpus Heterophyllus) waste. International Journal of Pharmacy and Pharmaceutical Sciences. 2014;6(9):473-478. 
25. Ziyan E, Pekyardimci S. Characterization of Polyphenol Oxidase from Jerusalem Artichoke (Helianthus tuberosus). Turk J Chem., 2003;27: 217- 225.

26. Doğan S, Turan Y, Ertürk $\mathrm{H}$, Arslan O. Characterization and Purification of Polyphenol Oxidase from Artichoke (Cynara scolymus L.). J Agric Food Chem. 2005;53(3):776-85.

27. YM, Yao LY, Shen W. Purification and Characterization of Polyphenol Oxidase from Jackfruit (Artocarpus heterophyllus) Bulbs. J Agric Food Chem. 2013;61(51):12662-9.

28. Gandia GF, Garcia CF, Escribano J. Purification and characterisation of a latent polyphenol oxidase from beetroot (Beta vulgaris L.). J Agric Food Chem. 2004;52:609-615.

29. Yoruk R, Marshall MR. Physicochemical properties and function of plant polyphenol oxidase: a review. Journal of Food Biochemistry. 2003;27(5):361-422.

30. Peng X, Du C, Yu H, Wang X. Purification and characterization of polyphenol oxidase (PPO) from water yam (Dioscorea alata). CyTAJournal of Food. 2019;17(1):676-684.

31. Teng J Gong Z , Deng $Y_{s}$ Chen Ls Li Q, Xiao W. Purification, characterization and enzymatic synthesis of theaflavins of polyphenol oxidase isozymes from tea leaf (Camellia sinensis). LWT. 2017;84:263-270.

32. Sanni D. Partial Purification and Characterisation of Polyphenol Oxidase from Two Commonly Consumed Eggplants (Solanum mellongena depressum and Solanum gilo) in Nigeria. Biochemistry and Molecular Biology. 2016;1(1):1-10.

33. Aydemir T. Partial purification and characterization of polyphenol oxidase from artichoke (Cynara scolymus L.) heads. Food chemistry. 2004;87(1):59-67.

34. Ali WI, Al-abbasy OY, Younis SA. Vanillic acid: an antioxidant used in preventing browning process in pear (Pyruscommunisl.) juice. Ann Rom Soc Cell Bio. 2020;25(3):5272-5285.

35. Rashan AI, Al-abbasy OY. Inhibitory and kinetic study of partially purified tyrosinase from Iraqi quince fruit. Plant Cell Biotech Mol Bio 2021; 22(23-24):1-14.
36. Gülçìn I, Küfrevİoğlu OI, Oktay $M$. Purification and characterization of polyphenol oxidase from nettle (Urtica dioica L.) and inhibitory effects of some chemicals on enzyme activity. J Enzyme Inhib Med Chem. 2005;20(3):297-302.

37. Samynathan R, Palanisamy ChP, Gandhi S, Perisamy S, Kanniappan GV. Isolation and characterization of polyphenol oxidase from upasi selected clone of Camellia sinensis (L.) O. kuntze. Indo American J. Pharm. Research. 2015;5(1):241-252.

38. Mansouritorghabeh H, Sankian M, Varasteh AR, Moghadam M, Khameneh B, Hosseini RF, et al. Determination of Optimum Excipients for Platanus orientalis Pollen Extract by Accelerating Chemical Stability Test and Their Synergistic Effect. Reports of Biochemistry \& Molecular Biology. 2019;7(2):189-195.

39. Moon KM, Kwon E, Choon Y. Recent Trends in Controlling the Enzymatic Browning of Fruit and Vegetable Products. Molecules. 2020;25(12):2754.

40. Gul Guven R, Aslan N, Guven K, Matpan Bekler F, Acer O. Purification and characterization of polyphenol oxidase from corn tassel. Cell. Mol. Biol. 2016;62 (13): 6-11.

41. Kim CY, Kim MJ, Lee MY, Park IS. Inhibition of polyphenol oxidase and peach juice browning by onion extract. Food Science and Biotechnology. 2007;16(3):421-425.

42. Kiattisin K, Nantarat Th, Leelapornpisid P. Evaluation of antioxidant and anti-tyrosinase activities as well as stability of green and roasted coffee bean extracts from Coffea arabica and Coffea canephora grown in Thailand. Journal of Pharmacognosy and Phytotherapy. 2016;8(10):182-192.

43. Michelle BS, Weerawardana GT, Priyani A. Natural Antibrowning Agents against Polyphenol Oxidase Activity in Annona muricata and Musa acuminata. Journal of Chemistry. 2020. 